\title{
EDITORIAL
}

\section{El acto médico, se construye desde el pregrado}

\section{Medical act, development from pregrade}

\author{
Frank Lizaraso Caparói,a,b
}

Hace unas décadas, el acto médico se circunscribía exclusivamente a la relación médico-paciente, donde el médico era el protagonista y el paciente, un "receptor silencioso" de indicaciones. La atención, por lo tanto; se basaba en la decisión del galeno, comprendida en su capacidad de diagnóstico y vocación de servicio sin que medie la opinión del "doliente". Hoy, el desarrollo tecnológico y la globalización, han generado un cambio significativo en la atención: el médico, debe escuchar y generar confianza en el paciente y su entorno.

Todo este proceso evolutivo, ha ido modificando el concepto de acto médico, siendo necesario considerar toda la actividad que realice el médico (investigación, docencia, función pública, administrativa, comunicacional y hospitalaria), el derecho del paciente y la necesidad del consentimiento informado $(1,2)$.

De allí, la necesidad de construir desde las Facultades de Medicina, las competencias que aseguren un buen acto médico, desde el pregrado. Es indispensable generar, en el ente universitario, la responsabilidad de formar profesionales de la salud, con la suficiente capacidad, para que cuando realicen alguna prestación de salud, sea mínima la posibilidad de cometer un error y generar la desconfianza y queja del paciente.

La universidad, tiene una serie de objetivos en la formación del médico. Uno de ellos, es formar médicos convencidos de que la medicina es una profesión de servicio y para ello debe tener actitud y aptitud de servicio y debe atender siempre con eficacia y eficiencia y con un enfoque integral de los problemas de salud más frecuentes del individuo, la familia y la sociedad (3).

Diversos humanistas y personalidades paradigmáticas de la medicina en el Perú, como: Honorio Delgado, entre otros, han enfatizado con esclarecida sapiencia que la esencia del humanismo es el amor al prójimo, razón de ser del acto médico a través de los tiempos (4).

Como decía el Profesor Gregorio Marañón: El médico tiene, como parte esencial de su trabajo, que enfrentarse al dolor humano, a la enfermedad y a la muerte. La primera obligación del médico humanista es "la de ser competente técnica y científicamente", independientemente del escenario en que se desempeñe (5).

El humanismo médico, puede ser una herramienta para la reorientación y crítica de la ética médica. Después de todo, el cuidado de la salud; está muy ligado al proyecto moral que toda Facultad de Medicina que se precie de moderna debe tener (6).

Uno de los aspectos esenciales, al que deberán atender las Facultades de Medicina del futuro, será que el estudiante comprenda que la autoformación será muy importante durante toda su vida profesional. Si de las universidades egresaran buenos clínicos, en el sentido correcto del calificativo, habría un mayor número de pacientes enfermos o dolientes curados, aliviados o confortados. 
Solamente el clínico que ofrece su servicio, cultivando sus conocimientos y aplicándolos con habilidad y humanidad podrá reforzar la vigencia del acto médico evitando su caducidad (7).

La Universidad de San Martin de Porres, baj o el lema: "Una Universidad para toda la vida", cumple a través de su Facultad de Medicina, con la formación integral del futuro médico peruano: científico, humanista, sensible a los cambios y necesidad de nuestra sociedad.

En conclusión, el acto Médico, se dará como resultado de la conducta y función del médico,que incluye: la relación médico-paciente, desde la etapa preliminar del conocimiento, hasta las etapas posteriores al tratamiento como son: la evolución y rehabilitación del paciente. Debiendo tener en cuenta que su participación directa, indirecta y documental, será consecuencia de las competencias generadas desde la Facultad de Medicina, en el pregrado.

\section{REFERENCIAS BIBLIOGRÁFICAS}

1. Guzmán F, Franco E, Morales de Barrios M, Mendoza J. El acto médico, implicaciones éticas y legales. Acta Médica Colombiana 1994; 19(3):139-149.

2. Varas J. Responsabilidad médica y acto médico. Rev Obstet Ginecol Hosp Santiago Oriente Dr. Luis Tisné Brousse 2011; 6 (3):240-244.

3. Pizarro C. Responsabilidad profesional médica: Diagnóstico y perspectivas. Rev Med Chile 2008; 136: 539-43.

4. Ramírez A. La faceta humana del médico. Diagnóstico 1995; 34(2):38-43.
5. Segredo A, Perdomo C. La Medicina General Integral y su enfoque social y humanista. Educ Med Super 2012; 26(2):294-306.

6. Lizaraso F. Humanismo médico, una competencia a desarrollar. Horiz Med 2011; 11(2):63-64.

7. Alhalel-Gabay B. Vigencia de los valores del acto médico y de la relación médico-paciente. Rev Soc Peru Med Interna 2008; 21 (1): 37-41. 